\title{
Perlindungan Hukum Anak Korban Kekerasan Seksual Dari Reviktimisasi Dalam Sistem Peradilan Pidana
}

\author{
Indriastuti Yustiningsih \\ Fakultas Hukum Universitas Islam Indonesia Yogyakarta Indonesia \\ Jln. Cik Di Tiro No. 1, Yogyakarta, Indonesia 55223 \\ farrayustisia@gmail.com
}

\begin{abstract}
Child victims of sexual violence who undergo the criminal justice process still experience revictimization when giving their testimony in court, child victims must remember and recount the chronology of the sexual violence they experienced, where it will cause psychological trauma that will take longer to heal and will affect the victim's future. Departing from this perspective, this study intends to examine the efforts to prevent the victimization of child sexual violence victims in the criminal justice system in Indonesia. This is an empirical research with an empirical juridical approach by examining how the law works in the society. This research concludes that in order to prevent the re-victimization of child victims of sexual violence in the criminal justice system, a legal policy is needed by making changes to the criminal procedural law. The provisions contained in Article 58 paragraph (3) letter (a) of Law Number 11 of 2012 on the Juvenile Criminal Justice System for Children can be applied as a basis for examining child victims since the beginning of the judicial process, in which electrocnic recording should be made during the investigation stage, oath-taking and making a Police Investigation Report (BAP), and it can be used as an admissible evidence in the argumentation, so that it is sufficient for the victim to provide information only at the investigation stage.
\end{abstract}

Key Words: Child victims; legal protection; re-victimization; sexual violence

\begin{abstract}
Abstrak
Anak korban kekerasan seksual yang menjalani proses peradilan pidana masih mengalami reviktimisasi saat memberikan keterangannya dipersidangan, korban anak harus mengingat dan menceritakan kembali kronologis peristiwa kekerasan seksual yang dialaminya, dimana hal tersebut akan menimbulkan trauma psikis yang akan lebih lama sembuhnya dan akan berpengaruh pada masa depan korban. Berangkat dari hal tersebut, penelitian ini bermaksud mengkaji bagaimana upaya pencegahan reviktimisasi terhadap anak korban kekerasan seksual dalam sistem peradilan pidana di Indonesia. Jenis penelitian yang digunakan bersifat empiris dengan pendekatan yuridis empiris, yakni dengan meneliti bagaimana bekerjanya hukum pada masyarakat. Penelitian ini menyhimpulkan untuk mencegah reviktimisasi terhadap anak korban kekerasan seksual dalam sistem peradilan pidana, perlu kebijakan hukum dengan melakukan perubahan hukum acara pidana. Ketentuan yang terdapat dalam Undang-Undang Nomor 11 Tahun 2012 tentang Sistem Peradilan Pidana Anak Pasal 58 ayat (3) huruf (a) dapat dijadikan sebagai dasar cara pemeriksaan terhadap anak korban sejak awal proses peradilan, dimana pada tahap penyidikan telah dilakukan perekaman eletronik, penyumpahan dan pembuatan BAP, dan dapat dijadikan sebagai alat bukti sah pada proses pembuktian, sehingga korban cukup sekali memberikan keterangan pada tahap penyidikan.
\end{abstract}

Kata-kata Kunci: Kekerasan seksual; korban anak; perlindungan hukum; reviktimisasi 


\section{Pendahuluan}

Anak sebagai amanah Tuhan Yang Maha Kuasa berhak mendapatkan perlindungan sejak dalam kandungan sampai dengan anak menjadi dewasa. Perlindungan mengenai anak ini sudah sejak lama dikemukakan. Gagasan mengenai hak anak bermula setelah berakhirnya Perang Dunia I. Sebagai reaksi atas penderitaan yang timbul akibat bencana peperangan terutama yang dialami oleh perempuan dan anak-anak. Seorang aktivis perempuan bernama Eglantyne Jeb mengembangkan 10 pernyataan hak-hak anak pada 1923 diadopsi oleh Save the Children Fund Internasional Union. Setelah berakhirnya perang dunia II, pada 10 Desember 1948 Majelis Umum PBB mengadopsi deklarasi hak asasi manusia, yang akhirnya 10 deklarasi pernyataan hak anak tersebut diadopsi dan dideklarasikan oleh PBB yaitu dalam konvensi hak anak pada 20 November 1989.

Konvensi hak anak tersebut merupakan instrumen Internasional dibidang Hak Asasi Manusia dengan cakupan hak yang paling komprehensif ${ }^{1}$, merupakan konvensi di bidang Hak Asasi Manusia yang mencakup hak-hak sipil dan politik maupun hak-hak ekonomi, sosial dan budaya.

Berkaitan dengan asas kepentingan terbaik bagi anak, dalam Pasal 3 ayat (1) Konvensi Hak Anak menyebutkan bahwa dalam semua tindakan yang menyangkut anak yang dilakukan oleh lembaga-lembaga kesejahteraan sosial pemerintah maupun swasta, lembaga peradilan, lembaga pemerintahan atau badan legislatif, maka kepentingan yang terbaik bagi anak harus menjadi pertimbangan utama. Hal ini disebabkan karena seorang anak belum memiliki kematangan fisik dan mental, sehingga membutuhkan perlindungan dan perawatan khusus, termasuk perlindungan hukum yang layak, sebelum dan sesudah kelahiran. ${ }^{2}$

Konvensi Hak Anak ini kemudian diratifikasi oleh Indonesia pada 25 Agustus 1990 melalui Keppres Nomor 36 Tahun 1990. Setelah melakukan ratifikasi mengenai hak anak tersebut, pada 2002 Indonesia mengundangkan Undang-Undang Nomor 23 Tahun 2002 tentang perlindungan anak. UndangUndang ini meletakkan kewajiban memberikan perlindungan kepada anak berdasarkan asas non diskriminasi, asas kepentingan yang terbaik bagi anak, asas hak hidup, kelangsungan hidup, dan pekermbangan dan asas penghargaan terhadap pendapat anak ${ }^{3}$.

\footnotetext{
Supriyadi W. Eddyono, "Pengantar Konvensi Hak Anak", http://lama.elsam.or.id/downloads/1262854039 20. Konvensi Hak Anak.pdf, diakses tanggal 5 Juli 2019.

${ }^{2}$ Ibid.

${ }^{3}$ Undang-Undang nomor 17 Tahun 2016 Tentang Penetapan Peraturan Pemerintah Pengganti UndangUndang nomor 1 Tahun 2016 tentang Perubahan Kedua atas Undang-undang Nomor 23 Tahun 2002 tentang Perlindungan Anak menjadi Undang-Undang
} 
Undang-Undang ini mendefinisikan apa yang dimaksud dengan anak yaitu pada Pasal 1 angka 1, anak adalah seseorang yang belum berusia 18 tahun, termasuk anak yang masih dalam kandungan, selanjutnya dalam angka 2 memberikan pengertian mengenai perlindungan anak adalah segala kegiatan untuk menjamin dan melindungi anak dan hak-haknya agar dapat hidup, tumbuh, berkembang dan berpartisipasi, secara optimal sesuai dengan harkat dan martabat kemanusiaan, serta mendapat perlindungan dari kejahatan dan diskriminasi. ${ }^{4}$

Undang-Undang tersebut juga menekankan akan tanggung jawab negara, keluarga dan masyarakat dalam rangka memberikan perlindungan terhadap anak, hal ini disebabkan anak adalah merupakan individu yang belum matang baik secara fisik, mental maupun sosial, sehingga rentan mengalami tindakan kejahatan, eksploitasi, penelantaran, perdagangan, diskriminasi dan sebagainya. Oleh karena itu komite anak PBB dalam pedoman laporan untuk negara peserta mengkategorikan anak-anak yang membutuhkan upaya perlindungan khusus tersebut, yaitu : ${ }^{5} 1$. Anak yang berada dalam situasi darurat, yakni pengungsi anak dan anak yang berada dalam situasi konflik bersenjata. 2. Anak yang mengalami masalah dengan hukum. 3. Anak yang mengalami situasi eksploitasi, meliputi eksploitasi ekonomi, penyalahgunaan obat dan substan, eksploitasi seksual, penjualan dan perdagangan anak dan yang mengalami bentuk-bentuk eskploitasi lainnya. 4. Anak yang berasal dari kelompok minoritas dan masyarakat adat.

Usaha pemerintah untuk melindungi anak dengan Undang-Undang Nomor 23 Tahun 2002 tentang Perlindungan Anak ini ternyata belum mampu melindungi anak secara baik, meskipun telah adanya peraturan hukum yang mengatur tentang perlindungan anak ini, permasalahan hukum terhadap anak semakin lama semakin mengkuatirkan, terutama permasalahan anak sebagai korban kejahatan seksual baik itu perbuatan pencabulan atau perkosaan. Bahkan pernah terjadi peristiwa kejahatan seksual dalam lingkup rumah tangga yang dilakukan oleh kakak terhadap adik kandungnya yang ternyata alasannya adalah kakak kandungnya yang berusia 18 tahun mempraktekkan adegan porno yang baru saja dilihatnya melalui media handphone yang dimilikinya.

Dampak negatif perkembangan teknologi yang menyebabkan semua orang mudah mengakses berita dan situs-situs pornografi telah membawa akibat yang sangat buruk bagi keselamatan anak-anak sebagai generasi penerus bangsa. Keselamatan anak-anak terutama anak perempuan saat ini sangat memprihatinkan. Anak sebagai generasi penerus harus mendapatkan perlindungan yang baik agar

${ }^{4}$ Undang-Undang Nomor 23 Tahun 2002 tentang Perlindungan Anak

${ }^{5}$ Supriyadi W. Eddyono, Loc. Cit., hlm. 4. 
tidak mengalami keadaan buruk akibat adanya kejahatan seksual yang dilakukan oleh orang-orang yang tidak bertanggungjawab.

Maraknya kejahatan seksual terhadap anak menjadikan pemerintah memberikan perhatian dan komitmen untuk mengatasi hal tersebut, hingga kemudian lahirlah Undang-Undang Nomor 35 Tahun 2014 tentang perubahan atas Undang-Undang Nomor 23 Tahun 2002 tentang Perlindungan Anak yang dibuat dengan maksud untuk menyempurnakan Undang-Undang sebelumnya sehingga anak korban terutama korban kekerasan seksual dapat lebih terlindungi. Pengaturan terkait dengan perbuatan kekerasan seksual terhadap anak dalam Undang-Undang ini adalah dalam ancaman pidana memberikan pemberatan sanksi pidana dan denda terhadap pelaku kejahatan terhadap anak, dengan tujuan untuk memberikan efek jera, serta mendorong adanya langkah konkrit untuk memulihkan kembali fisik, psikis dan sosial anak korban.

Pemberatan sanksi pidana bagi pelaku kekerasan seksual terhadap anak dalam Undang-Undang ini ternyata belum mampu memberikan efek jera kepada pelaku dengan bukti makin naiknya data kekerasan seksual dari tahun ke tahun, hingga kemudian pada 2016, terjadi peristiwa pemerkosaan terhadap Yuyun oleh 14 orang pemuda yang mengakibatkan korban meninggal dunia. Atas peristiwa tersebut membuat berbagai elemen masyarakat bereaksi keras dan meminta pemerintah bersikap tegas terhadap pelaku kekerasan seksual terhadap anak. Atas keadaan tersebut, pemerintah menyatakan kejahatan seksual terhadap anak sebagai kejahatan yang luar biasa, sehingga pemerintah mengeluarkan Perppu Nomor 1 Tahun 2016 tanggal 25 Mei 2016 tentang perubahan kedua atas UndangUndang Nomor 23 Tahun 2002 tentang perlindungan anak yang kemudian ditetapkan menjadi Undang-Undang yaitu Undang-Undang Nomor 17 Tahun 2016. Undang-Undang Nomor 17 Tahun 2016 pada pokoknya memperberat pidana penjara dan denda apabila perbuatan pelaku menimbulkan korban lebih dari satu orang, mengakibatkan luka berat, gangguan jiwa, penyakit menular, terganggu atau hilangnya fungsi reproduksi, dan/ atau korban meninggal dunia. Pidana tambahan berupa pengumuman identitas pelaku serta tindakan berupa kebiri kimia, pemasangan alat pendeteksi elektronik dan rehabilitasi.

Apabila diperhatikan ketiga Undang-Undang tersebut dibuat dengan maksud akan melindungi anak korban dari kejahatan-kejahatan yang mungkin akan timbul kepadanya terutama kejahatan seksual dengan cara memberikan hukuman yang maksimal kepada pelaku kejahatan, namun faktanya dari hari ke hari kejadian kejahatan seksual terhadap anak semakin meningkat, sanksi hukuman yang diperberat ternyata belum mampu membuat pelaku kejahatan 
jera untuk melakukannya, akibatnya jumlah anak yang mengalami korban kejahatan seksual makin bertambah.

Hak-hak anak korban yang harus dilindungi terutama hak anak korban kekerasan seksual pasca kejadian yang menimpanya seolah diabaikan. Anak korban yang telah mengalami kekerasan seksual tentu akan mengalami trauma yang mendalam, belum lagi ketika anak korban atau orang tuanya melaporkan kejadian tersebut ke pihak kepolisan. Ketika memberikan laporannya anak korban akan diminta memberikan keterangan secara lengkap, detail atas peristiwa yang dialaminya, sehingga mau tidak mau anak korban harus mengingat semua kejadian yang telah membuatnya sakit, baik fisik maupun psikis. Belum lagi ketika anak korban menjalani persidangan untuk mengungkap perbuatan pelaku terhadapnya, belum sembuh luka yang dialaminya akan timbul luka baru lagi ketika harus menjelaskan kembali kejadian yang menimpanya.

Kekerasan seksual yang menimpa anak dapat mengakibatkan anak mengalami trauma, diantaranya depresi, sindrom trauma perkosaan (rape trauma syndrome/RTS), disosiasi (pelepasan dari realitas), gangguan makan, Hypoactive Sexual Desire Disorder (kondisi medis yang menandakan hasrat seksual rendah), Dyspareunia (nyeri yang dirasakan selama atau setelah berhubungan seksual), vaginismus (otot-otot vagina meremas atau mengejang dengan sendirinya). ${ }^{6}$

Oleh karena itu anak sebagai korban kekerasan seksual harus mendapatkan perlindungan agar merasa aman dan tidak akan terulang lagi trauma yang pernah dialaminya. Sehingga terhadap anak yang mengalami kekerasan seksual yang telah melaporkan kejadian tersebut kepada pihak kepolisian sedapat mungkin harus segera mendapatkan penanganan yang baik, baik secara medis maupun psikis, jangan sampai proses mencari keadilan malah akan menjadikan traumatik yang berkepanjangan. Korban perlu mendapatkan dukungan yang tepat dari keluarga, masyarakat dan aparat penegak hukum ketika laporannya ditindaklanjuti, serta dari psikolog, lembaga sosial atau lembaga swadaya masyarakat yang peduli terhadap korban.

Perlindungan terhadap anak korban kekerasan seksual dalam proses peradilan pidana harus mendapatkan perhatian. Sistem peradilan pidana Indonesia yang terdiri dari beberapa sub sistem harus secara terpadu dan sejalan dalam memberikan perlindungan terhadap anak korban. Pemerintah sebagai pengambil kebijakan dalam menentukan ketentuan hukum harus membuat

6 Ajeng Quamila, "8 Trauma Fisik dan Mental Akibat Kekerasan Seksual", https://hellosehat.com/hidup-sehat/psikologi/trauma-akibat-kekerasan-seksual/, diakses pada Maret 2020. 
aturan yang benar-benar memberikan perlindungan kepada anak korban tidak hanya secara fisik maupun materi tetapi juga perlindungan secara psikis, sehingga trauma yang dialaminya segera pulih.

Pengaturan perlindungan terhadap korban dalam Kitab Undang-Undang Hukum Acara Pidana (KUHAP) masih terbatas pada perlindungan secara materi, yaitu berkaitan dengan ganti kerugian yang dapat dimintakan melalui gugatan yang diajukan bersama dengan perkara pokoknya, namun hal semacam itu sangat jarang terjadi dalam proses peradilan di Indonesia. Apabila suatu tindak pidana telah diproses secara pidana maka hanya hukuman badan dan atau denda saja yang akan dijatuhkan kepada pelaku tindak pidana. Pengaturan mengenai adanya kompensasi, restitusi dan rehabilitasi dalam Undang-Undang Perlindungan Saksi Dan Korban pun belum bisa dilaksanakan secara baik untuk melindungi korban.

Undang-Undang Nomor 11 Tahun 2012 tentang Sistem Peradilan Pidana Anak lahir sebagai pengganti Undang-Undang Nomor 3 Tahun 1997 tentang Pengadilan Anak yang sudah tidak relevan lagi dengan perkembangan pembangunan dan kemajuan teknologi informasi. Undang-Undang ini tidak saja mengatur tentang hak dan kewajiban anak yang melakukan tindak pidana namun juga hak dan kewajiban anak sebagai anak korban ataupun anak saksi yang menjalani proses persidangan. Ketentuan tersebut dapat ditemukan dalam Pasal 58 ayat (1) ayat (2) dan ayat (3) Undang-Undang Nomor 11 Tahun 2012 tentang Sistem Peradilan Pidana Anak yaitu:

Ayat (1) Pada saat memeriksa anak korban dan/atau anak saksi, Hakim dapat memerintahkan agar anak dibawa keluar ruang sidang.

Ayat (2) Pada saat pemeriksaan anak korban dan/atau anak saksi sebagaimana dimaksud pada ayat (1), orang tua/wali, advokat atau pemberi bantuan hukum lainnya, dan Pembimbing Kemasyarakatan tetap hadir.

Ayat (3) Dalam hal anak korban dan / atau anak saksi tidak dapat hadir untuk memberikan keterangan di depan sidang pengadilan, hakim dapat memerintahkan anak korban dan / atau anak saksi di dengar keterangnnya:

a. Di luar sidang pengadilan melalui perekaman elektonik yang dilakukan oleh Pembimbing Kemasyarakatan di daerah hukum setempat dengan dihadiri oleh Penyidik atau Penuntut Umum dan Advokat atau pemberi bantuan hukum lainnya; atau

b. Melalui pemeriksaan langsung jarak jauh dengan alat komunikasi audiovisual dengan didampingi oleh orang tua/wali, Pembimbing Kemasyarakatan atau pendamping lainnya.

Ketentuan dalam Pasal 58 diatas mengatur bagaimana seorang anak korban dan/atau anak saksi dapat memberikan keterangannya di persidangan. namun

7 Undang-Undang Nomor 11 Tahun 2012 tentang Sistem Peradilan Pidana Anak. 
demikian keterangan yang harus diberikan lagi oleh anak korban kekerasan seksual pada saat persidangan, untuk membuktikan perbuatan terdakwa terhadap anak korban serta anak korban berhadapan dengan terdakwa selaku orang yang telah melakukan kejahatan terhadapnya sama halnya akan mengungkit kembali peristiwa yang sebenarnya tidak diinginkannya untuk diingat kembali. Pada posisi ini anak korban kekerasan seksual akan menjadi korban kembali atau mengalami reviktimisasi (secondary victimisation). Hal tersebut membuat enggan para korban maupun keluarganya untuk melaporkan kejadian yang menimpa korban atau keluarganya karena pertimbangan psikologis korban. Keadaaan seperti itu tentu menjadi catatan dan merupakan tanggung jawab negara, bagaimana agar anak korban maupun keluarganya tidak enggan untuk melaporkan peristiwa yang dialaminya atau keluarganya dengan tetap merasa nyaman, aman, tidak mengalami reviktimisasi lagi dan perbuatan pelaku mendapatkan balasan yang setimpal.

\section{Rumusan Masalah}

Berdasarkan pada rumusan latar belakang permasalahan tersebut, maka dapat dirumuskan permasalahan bagaimana upaya pencegahan reviktimisasi terhadap anak korban kekerasan seksual dalam sistem peradilan pidana di Indonesia.

\section{Tujuan Penelitian}

Tujuan dari penelitian ini adalah untuk mengetahui bagaimana upaya pencegahan reviktimisasi terhadap anak korban kekerasan seksual dalam sistem peradilan pidana di Indonesia.

\section{Metode Penelitian}

Penelitian hukum ini menggunakan jenis penelitian empiris, dengan menggunakan pendekatan yuridis empiris/yuridis sosiologis yaitu penelitian dengan melakukan pendekatan yuridis (hukum sebagai das sollen) yang disandingkan dengan penelitian dengan melakukan pendekatan sosiologis (hukum sebagai realita/kenyataan sosial), meneliti bagaimana bekerjanya hukum pada masyarakat. Data yang digunakan meliputi data primer yang dilakukan dengan wawancara langsung ke sumbernya dan data sekunder yang terdiri dari bahan hukum primer, bahan hukum sekunder dan bahan hukum tersier. Data 
yang terkumpul kemudian dianalisis dengan menggunakan teknik analisis deskriptif kualitatif ${ }^{8}$ yaitu teknik analisa dengan cara memberikan gambaran atau penjabaran terhadap data yang telah terkumpul dalam bentuk uraian kalimat sehingga pada akhirnya mengantarkan pada kesimpulan.

\section{Hasil Penelitian dan Pembahasan}

Undang-Undang Dasar Negara Republik Indonesia dalam Pasal 1 ayat (3) berbunyi bahwa "Indonesia adalah negara hukum". Selanjutnya Pasal 27 ayat (1) UUD 1945 menegaskan "segala warga negara bersamaan kedudukkannya di dalam hukum dan pemerintahan dan wajib menjunjung hukum dan pemerintahan itu dengan tidak ada kecualinya". Pasal tersebut menegaskan bahwa hal penting dalam negara hukum adalah adanya penghargaan dan komitmen menjunjung tinggi hak asasi manusia serta menjamin semua warga negara bersamaan kedudukannya di dalam hukum (equality before the law). ${ }^{9}$ Dengan demikian negara mempunyai kewajiban untuk menjamin hak-hak setiap warga negaranya untuk mendapatkan perlindungan dalam hukum. Perlindungan hukum negara ini diberikan kepada warga negaranya tidak terkecuali baik selaku korban maupun pelaku. Untuk memberikan kepastian dalam pemberian perlindungan hukum tersebut, negara melalui perangkatnya menyusun peraturan yang dituangkan dalam bentuk peraturan perundangan-undangan yang berfungsi untuk mengatur warga negaranya untuk menjalankan hak dan kewajiban.

Perlindungan hukum terhadap warga negara dapat dilaksanakan baik secara preventif maupun represif, sebagaimana yang dikemukakan oleh Phillipus M Hadjon yaitu Perlindungan hukum bagi rakyat sebagai tindakan pemerintah yang bersifat preventif dan represif. Perlindungan hukum yang preventif bertujuan untuk mencegah terjadinya sengketa, yang mengarahkan tindakan pemerintah bersikap hati-hati dalam pengambilan keputusan berdasarkan diskresi, dan perlindungan yang represif bertujuan untuk menyelesaikan terjadinya sengketa termasuk penangannya di lembaga peradilan.10

CTS Kansil memberikan pengertian tentang perlindungan hukum yaitu berbagai upaya hukum yang harus diberikan oleh aparat penegak hukum untuk memberikan rasa aman, baik secara pikiran maupun fisik dari gangguan dan berbagai ancaman pihak manapun. ${ }^{11}$

\footnotetext{
${ }^{8}$ Burhan Ashofa, Metode Penelitian Hukum, Rhineka Cipta, Jakarta, 2004, hlm. 37.

${ }_{9}$ Bambang Waluyo, Viktimologi Perlindungan Saksi dan Korban, cetakan keenam, Sinar Grafika, Jakarta, 2018, hlm. 1.

10 Phillipus M. Hadjon, Perlindungan Hukum Bagi Rakyat Indonesia, Bina Ilmu, Surabaya, 1987, hlm. 29.

${ }^{11}$ CTS Kansil, Pengantar Ilmu Hukum dan Tata Hukum Indonesia, Balai Pustaka, Jakarta, 1989.
} 
Dengan demikian perlindungan hukum adalah usaha pemerintah untuk mencegah terjadinya kesewenang-wenangan baik yang dilakukan oleh aparatur pemerintah maupun oleh warga masyarakat satu terhadap yang lain. Perlindungan ini tidak terbatas pada perlindungan fisik saja namun juga perlindungan psikis (pikiran).

Pasal 28B ayat (2) Undang-Undang Dasar 1945 menyatakan "setiap anak berhak atas kelangsungan hidup, tumbuh dan berkembang serta berhak atas perlindungan dari kekerasan dan diskriminasi. Konsekuensi dari ketentuan pasal 28B tersebut perlu ditindaklanjuti dengan membuat kebijakan pemerintah yang bertujuan melindungi anak. Anak perlu mendapat perlindungan dari dampak negatif perkembangan pembangunan yang cepat, arus globalisasi di bidang komunikasi dan informasi, kemajuan ilmu pengetahuan dan teknologi. ${ }^{12}$

Pengertian anak menurt konvensi hak-hak anak memberikan pengertian anak adalah setiap manusia yang berusia dibawah delapan belas tahun kecuali, berdasarkan Undang-Undang yang berlaku untuk anak-anak, kedewasaan telah dicapai lebih cepat.

Undang-Undang Nomor 39 Tahun 1999 tentang Hak Asasi Manusia mendefinisikan anak adalah setiap manusia yang berusia dibawah 18 tahun dan belum menikah, termasuk aak yang masih dalam kandungan apabila hal tersebut adalah demi kepentingannya.

Pengertian anak menurut pasal 1 ayat (1) Undang-Undang Nomor 35 Tahun 2014 tentang perubahan atas Undang-Undang Nomor 23 Tahun 2002 tentang Perlindungan Anak adalah seseorang yang belum berusia 18 (delapan belas) tahun, termasuk anak yang masih dalam kandungan.

Melihat pada beberapa pengertian tersebut, maka yang disebut anak adalah setiap manusia baik laki-laki maupun perempuan yang masih ada dalam kandungan sampai dengan anak berusia 18 tahun atau sampai dengan anak tersebut menikah.

Menurut Maidin Gultom perlindungan anak adalah segala usaha yang dilakukan untuk menciptakan kondisi agar setiap anak dapat melaksanakan hak dan kewajibannya demi perkembangan dan pertumbuhan anak secara wajar baik fisik, mental dan sosial.13 Perlindungan anak dapat juga diartikan sebagai segala upaya yang ditujukan untuk mencegah, rehabilitasi dan memberdayakan anak

\footnotetext{
12 Penjelasan Undang-Undang Republik Indonesia Nomor 11 Tahun 2012 tentan SIstem Peradilan Pidana Anak.

13 Maidin Gultom, Perlindungan Hukum terhadap Anak dalam Sistem Peradilan Pidana Anak di Indonesia, cetakan keempat, Refika Aditama, Bandung, 2014, hlm. 40.
} 
yang mengalami tindak perlakuan salah (child abused), eksploitasi dan penelantaran, agar dapat menjamin kelangsungan hidup dan tumbuh kembang anak secara wajar, baik fisik, mental dan sosialnya. ${ }^{14}$

Berkaitan dengan hak-hak anak, ada empat prinsip yang terkandung dalam konvensi hak anak yang harus menjadi perhatian dari negara-negara peserta, yakni $^{15}$ : a. Prinsip non-diskriminasi; b. Prinsip yang terbaik bagi anak (best interest of the child); c. Prinsip atas hak hdup, kelangsungan dan perkembangan (the right to life, survival and development); d. Prinsip penghargaan terhadap pendapat anak (respect for the views of the child)

Perlindungan terhadap anak oleh pemerintah tidak hanya dilakukan terhadap anak yang berhadapan dengan hukum namun juga terhadap anak yang menjadi korban tindak pidana. Pasal 1 ayat (2) Undang-Undang Nomor 11 Tahun 2012 tentang Sistem Peradilan Pidana Anak menyebutkan bahwa yang dimaksud dengan anak yang berhadapan dengan hukum adalah anak yang berkonflik dengan hukum, anak yang menjadi korban tindak pidana, dan anak yang menjadi saksi tindak pidana.

Perlindungan terhadap diri anak sebagai korban tindak pidana dalam proses peradilan pidana selama ini masih minim sekali, meskipun telah ada beberapa kali perubahan dalam Undang-Undang perlindungan anak, namun perubahan tersebut adalah pada penjatuhan hukuman terhadap pelaku tindak pidana terhadap anak bukan berkaitan dengan perlindungan yang diberikan oleh pemerintah terhadap korban itu sendiri, terutama perlindungan psikis korban yang mengalami tindak pidana kejahatan seksual, sehingga dikuatirkan anak korban tindak pidana yang melaporkan tindak pidana yang terjadi padanya malah akan menjadi korban kembali (reviktimisasi).

Perlindungan hukum terhadap anak sebagai korban tindak pidana harus mendapatkan perhatian yang serius, baik perlindungan untuk mendapatkan hakhaknya sebagai korban maupun perlindungan pada saat proses pencarian keadilan melalui proses peradilan pidana terpadu (integrated criminal justice system).

Menurut Arif Gosita dalam Bambang Waluyo ${ }^{16}$ yang dimaksud dengan korban adalah mereka yang menderita jasmaniah dan rohaniah sebagai akibat tindakan orang lain yang mencari pemenuhan diri sendiri atau orang lain yang bertentangan dengan kepentingan dan hak asasi yang menderita.

Muladi mengartikan korban kejahatan sebagai seseorang yang telah menderita kerugian sebagai akibat suatu kejahatan dan atau yang rasa

\footnotetext{
${ }^{14}$ Ibid., hlm. 42.

${ }^{15}$ Supriyadi W. Eddyono, Loc. Cit., diakses tanggal 21 Juli 2020. 16 Bambang Waluyo, Op. Cit., hlm. 9.
} 
keadilannya secara langsung telah terganggu sebagai akibat pengalamannya sebagai target (sasaran) kejahatan. ${ }^{17}$

Dari pendapat tersebut yang dimaksud dengan korban (victim) adalah adanya penderitaan baik fisik maupun psikis dan perbuatan yang dialami korban tersebut akibat perbuatan melanggar hak-hak korban.

Perlindungan korban menurut Barda Nawawi Arief, dapat dilihat dari dua makna yaitu18: a. Dapat diartikan sebagai "perlindungan hukum untuk tidak menjadi korban tindak pidana" (berarti perlindungan HAM atau kepentingan hukum seseorang; b. Dapat diartikan sebagai "perlindungan untuk memperoleh jaminan/santunan hukum atas penderitaan/kerugian orang yang telah menjadi korban tindak pidana" (jadi identik dengan "penyantunan korban"). Bentuk santunan itu dapat berupa pemulihan nama baik (rehabilitasi), pemulihan keseimbangan batin (antara lain dengan permaafan) pemberian ganti rugi (restitusi, kompensasi, jaminan/santunan kesejahteraan sosial) dan sebagainya.

Perlindungan terhadap korban tindak pidana kejahatan seksual dalam penerapan di dalam praktek peradilan selama ini belum dapat memberikan perlindungan sepenuhnya terhadap korban terutama secara psikis karena pada setiap tahapan pada masing-masing subsistem peradilan pidana (Kepolisian, Kejaksaan, Pengadilan) akan mengungkap perbuatan tersangka/terdakwa dengan cara melakukan pemeriksaan saksi terutama saksi korban sehingga saksi yang dimintai keterangan atas perbuatan yang menimpanya akan selalu teringat akan peristiwa yang dialami sehingga kesempatan untuk memulihkan luka psikis akan semakin sulit. Menurut Achie Sudiarti Luhulima dalam Atikah Rahmi ${ }^{19}$, dalam memperlakukan korban selama proses peradilan pidana, aparat penegak hukum (polisi, jaksa, hakim) masih memperlakukan korban kekerasaan seksual sebagai obyek, bukan subjek yang harus didengarkan dan dihormati hak-hak hukumnya. Secara tidak langsung proses yang demikian akan menjadikan korban sebagai korban untuk kedua kalinya atau korban akan mengalami reviktimisasi atas kasus yang dialaminya. Korban masih sering dipersalahkan dan tidak diberi perlindungan seperti apa yang dibutuhkannya. Akibatnya, semakin banyak kasus tidak dilaporkan atau malah ditarik kembali dan tidak dilanjutkan ke pengadilan. Hal ini menambah deretan kekerasan terselubung tanpa pernah terungkap dan para pelakunya bebas dari jeratan hukum.

${ }^{17}$ Muladi dan Barda Nawawi Arif, Bunga Rampai Hukum Pidana, Alumni, Bandung, 2010, hlm. 84.

18 Barda Nawawi Arief, Masalab Penegakan Hukum dan Kebijakan Hukum Pidana dalam Penanggulangan Kejahatan, Kencana, Jakarta, 2014, hlm. 61-62.

19 Atikah Rahmi "Urgensi Perlindungan bagi korban kekerasan seksual dalam sistem peradilan pidana terpadu berkeadilan gender”, Mercatoria, vol. 11 (1), 2018, hlm. 51. 
Undang-Undang Sistem Peradilan Pidana Anak yang merupakan lex spesialis dari KUHAP, telah mengupayakan keadilan restoratif dengan melaksanakan diversi yang merupakan perwujudan dari mediasi penal. Diversi ini merupakan upaya pemerintah untuk melindungi anak yang melakukan tindak pidana sedapat mungkin menyelesaikan permasalahan tanpa melalui proses persidangan, sehingga trauma dapat diminimalisir dan tingkahlaku serta masa depan anak masih bisa diperbaiki. Kekhususan Undang-Undang Sistem Peradilan Pidana Anak ini ternyata belum menyentuh kepada anak selaku korban tindak pidana, dalam hukum acara untuk anak selaku korban yang bersaksi masih sama dengan KUHAP, dalam Pasal 58 hanya memberikan alternatif saja apabila anak korban berhalangan untuk hadir, dengan demikian masih ada kewajiban dari anak korban untuk tetap menyelesaikan permasalahannya dengan proses persidangan, sedangkan untuk anak pelaku malahan ada kesempatan untuk tidak menjalani proses persidangan. Akibatnya makin banyak korban atau orangtuanya yang tidak mau melaporkan peritiwa yang dialaminya atau dialami anaknya demi kesehatan mental/psikis anak tersebut.

Upaya untuk meminimalisir terjadinya korban untuk tidak menjadi korban untuk kedua kalinya adalah dengan adanya saling dukung antar subsistem dalam sistem peradilan pidana. Menurut Rusli Muhammad sistem peradilan pidana disingkat SPP adalah jaringan peradilan yang bekerja sama secara terpadu diantara bagian-bagiannya untuk mencapai tujuan tertentu baik jangka pendek maupun jangka panjang. ${ }^{20}$ Sistem peradilan pidana di dalamnya terkandung gerak sistemik dari subsistem pendukungnya, yakni Kepolisian, Kejaksaan, Pengadilan, Lembaga Pemasyarakatan, yang secara keseluruhan dan merupakan suatu kesatuan (totalitas) berusaha mentransformasikan masukan menjadi luaran yang menjadi tujuan sistem peradilan pidana yaitu menanggulangi kejahatan atau mengendalikan kejadian kejahatan agar berada dalam batas-batas toleransi yang dapat diterima masyarakat. ${ }^{21}$

Menurut Mardjono Reksodiputro dalam Atikah Rahmi ${ }^{22}$ yang dimaksud sistem peradilan pidana (criminal justice system) adalah sistem yang dibuat untuk menanggulangi masalah-masalah kejahatan yang dapat mengganggu ketertiban umum dan mengancam rasa aman dalam suatu masyarakat. Konsep sistem peradilan pidana yang dikenal di Indonesia ialah suatu keadaan dimana terjalinnya hubungan yang bersifat fungsionaal dan instansional yaitu koordinasi diantara subsistem satu dengan lainnya menurut fungsi dan kewenangan yang

${ }^{20}$ Rusli Muhammad, Sistem Peradilan Pidana Indonesia, UII Press, Yogyakarta, 2011, hlm. 1.

${ }^{21}$ Ibid., hlm. 13.

22 Atikah Rahmi, Loc. Cit., hlm. 54. 
diatur dalam hukum acara pidana dalam rangka penegakan hukum pidana yang berlaku. Koordinasi yang dilakukan dengan baik untuk mengungkap kejahatan pelaku dengan melibatkan korban selaku salah satu saksi mulai dari subsistem kepolisian sampai dengan subsistem pengadilan perlu dilaksanakan untuk meminimalisir trauma psikis.

Proses peradilan pidana di Indonesia dilaksanakan dengan mendasarkan pada Undang-Undang Nomor 8 Tahun 1982 tentang Hukum Acara Pidana yang kemudian dikenal dengan Kitab Undang-Undang Hukum Acara Pidana (KUHAP). Kitab Undang-Undang Hukum Acara Pidana tersebut mengatur tata cara proses peradilan dari masing-masing subsistem yaitu subsistem penyidikan, subsistem Kejaksaan, Subsistem Pengadilan guna mencapai tujuan penegakan hukum.

Pembuktian terhadap perkara yang diajukan oleh jaksa penuntut umum ke persidangan memegang peranan yang sangat penting untuk menemukan kebenaran materiil. Dalam rangka menemukan kebenaran materiil tersebut, jaksa penuntut umum melakukan pembuktian dengan alat-alat bukti sebagaimana diatur dalam Pasal 184 ayat (1) KUHP yang mengatur mengenai alat bukti yang sah antara lain adalah: 1. Keterangan saksi; 2. Keterangan ahlip; 3. Surat; 4. Petunjuk; 5. Keterangan terdakwa.

Keterangan saksi ditempatkan pada urutan pertama karena sebagaimana ketentuan pasal 1 angka 27 Keterangan saksi adalah salah satu alat bukti dalam perkara pidana yang berupa keterangan dari saksi mengenai suatu peristiwa pidana yang ia dengar sendiri, ia lihat sendiri dan ia alami sendiri dengan menyebut alasan pengetahuan itu. Kesaksian seseorang yang menjadi saksi dipersidangan diurutkan dari orang yang menjadi korban sebagaimana ketentuan Pasal 160 ayat (1) huruf b KUHAP yaitu, "Yang pertama-tama di dengar keterangannya adalah korban yang menjadi saksi."

Seorang anak yang mendengar sendiri, melihat sendiri, dan/atau mengalami sendiri suatu peristiwa pidana juga dapat menjadi saksi, hal tersebut sebagaimana diatur dalam KUHAP Pasal 1 angka 29 yang menjelaskan bahwa:

Keterangan anak adalah keterangan yang diberikan oleh seorang anak tentang hal yang diperlukan untuk membuat terang suatu perkara pidana guna kepentingan pemeriksaan dalam hal serta menurut cara yang diatur dalam Undang-Undang ini.

Pengaturan tentang anak yang menjadi saksi juga terdapat dalam UndangUndang Nomor 11 Tahun 2012 tentang Sistem Peradilan Pidana Anak dalam Pasal 1 angka 1: 
Anak yang menjadi saksi tindak pidana yang selanjutnya disebut anak saksi adalah anak yang belum berumur 18 (delapan belas) tahun yang dapat memberikan keterangan guna kepentingan penyidikan, penuntutan, dan pemeriksaan di sidang pengadilan tentang suatu perkara pidana yang didengar, dilihat, dan/atau dialaminya sendiri.

Pasal 1 angka 4 menjelaskan mengenai anak yang menjadi korban tindak pidana yang selanjutnya disebut anak korban adalah anak yang belum berumur 18 tahun, yang mengalami penderitaan fisik, mental, dan/atau kerugian ekonomi yang disebabkan oleh tindak pidana.

Dalam peristiwa kekerasan seksual yang dialami oleh anak dalam hal ini anak korban, karena anak tersebut telah mengalami sendiri atas peristiwa tersebut sesuai dengan ketentuan Pasal 184 ayat (1) huruf a maka ia harus menjadi saksi dalam rangka pembuktian dipersidangan. Namun sebagaimana telah penulis uraikan diatas bahwa anak korban kekerasan seksual yang menghadapi proses peradilan pidana karena peristiwa yang dialaminya dilaporkan ke Kepolisian sebagai konsekuensinya anak korban telah mengalami penderitaan berupa psikis, fisik dan sosial dari tahap penyidikan hingga tahap persidangan. Setelah melaporkan peristiwa yang dialaminya, anak korban dimintai keterangan untuk mendapatkan informasi guna pengumpulan bukti-bukti awal, pada saat itu tentu kondisi psikisnya belum baik, namun harus menceritakan seluruh peristiwa yang bahkan tidak ingin diingatnya, belum lagi menderita trauma atau ketidaknyamanan psikisnya, sakit fisik yang dialami akibat kekerasan seksual yang tidak bisa serta merta disembuhkan serta rasa malu di dalam kehidupan sosialnya, baik lingkungan keluarga, sekolah atau masyarakat. Penderitaan-penderitaan itu apabila tidak segera mandapatkan perlindungan dan pendampingan bisa berakibat fatal terhadap masa depan anak korban.

Perlakuan proses peradilan yang demikian akan menjadikan anak korban sebagai korban untuk kedua kalinya (reviktimisasi) dan luka psikis yang belum benar-benar sembuh akan menjadi luka yang lebih dalam lagi yang mengakibatkan proses penyebuhan berjalan lebih lama dan menimbulkan bekas yang lebih dalam.

Undang-Undang nomor 11 Tahun 2012 tentang Sistem Peradilan Pidana Anak pada Pasal 58 ayat (3) sebenarnya sudah mengatur mengenai proses beracara untuk anak korban dan/atau anak saksi tanpa kehadirannya dipersidangan yaitu: 23

${ }^{23}$ Undang-Undang Nomor 11 Tahun 2012 Sistem Peradilan Pidana Anak. 
Dalam hal Anak Korban dan/atau Anak Saksi tidak dapat hadir untuk memberikan keterangan di depan sidang pengadilan, Hakim dapat memerintahkan Anak Korban dan/atau Anak Saksi di dengar keterangannya:

a. Diluar sidang pengadilan melalui perekaman elektronik yang dilakukan oleh Pembimbing Kemasyarakatan di daerah hukum setempat dengan dihadiri oleh Penyidik atau Penuntut Umum dan Advokat atau pemberi bantuan hukum lainnya; atau

b. Melalui pemeriksaan langsung jarak jauh dengan alat komunikasi audiovisual dengan didampingi oleh orang tua/wali, Pembimbing Kemasyarakatan atau pendamping lainnya.

Namun karena ketentuan ayat (3) huruf a dan b ini merupakan ketentuan alternatif ketiga maka dipersidangan hal semacam ini belum pernah dilakukan. Berdasarkan hasil wawancara terhadap psikolog pendamping dan pengamatan penulis dipersidangan langsung maupun melalui media elektronik lainnya, kehadiran anak korban untuk di dengar keterangannya adalah utama untuk membuktikan perbuatan terdakwa. Sehingga perlindungan anak korban pada proses ini sedikit diabaikan namun akan menimbulkan dampak yang besar terhadap anak korban.

Dalam permasalahan ini, Undang-Undang yang telah ada yang berkaitan dengan perlindungan anak, baik mengenai pemidanaan, gantirugi, restitusi maupun rehabilitasi, pada faktanya masih memberikan perlindungan secara materiil, perlindungan khusus sebagaimana ditentukan dalam Undang-Undang belum maksimal dilaksanakan, serta dalam tahap beracaranya terutama dalam pembuktian di persidangan belum mempertimbangkan dari aspek keselamatan psikologis anak korban. Oleh karena itu diperlukan adanya formulasi perubahan perundang-undangan oleh pembuat undang-undang agar perlindungan terhadap anak korban, terutama perlindungan psikisnya dapat dipenuhi.

Pengertian kebijakan atau politik hukum pidana dapat dilihat dari politik hukum maupun dari politik kriminal. Menurut Sudarto, politik hukum adalah ${ }^{24}$ : 1. Usaha untuk mewujudkan peraturan-peraturan yang baik sesuai dengan keadaan dan situasi pada suatu waktu. 2. Kebijakan dari negara melalui badanbadan yang berwenang untuk menetapkan peraturan-peraturan yang dikehendaki yang diperkirakan bisa digunakan untuk mengekspresikan apa yang terkandung dalam mayarakat dan untuk mencapai apa yang dicita-citakan.

Politik hukum pidana menurut Barda Nawawi Arief mengandung arti bagaimana mengusahakan atau membuat dan merumuskan suatu perundang-

24 "Pengertian dan ruang lingkup kebijakan hukum pidana", http://www.definisipengertian.com/2015/05/pengertian-ruang-lingkup-kebijakan-hukum.html, diakses tanggal 2 Agustus 2020. 
undangan pidana yang baik. Menurut A. Mulder yang dikutip oleh Barda Nawawi Arief, bahwa "Strafrechtspolitiek" ialah garis kebijakan untuk menentukan ${ }^{25}$ : 1 . seberapa jauh ketentuan-ketentuan pidana yang berlaku perlu diubah atau diperbaharui; 2. apa yang dapat diperbuat untuk mencegah terjadinya tindak pidana; 3. cara bagaimana penyidikan, penuntutan, peradilan dan pelaksanaan pidana harus dilaksanakan.

Perubahan Undang-Undang perlindungan anak dari Undang-Undang Nomor 23 Tahun 2003 hingga perubahan ketiga yaitu Undang-Undang Nomor 17 Tahun 2016, pada inti substansinya adalah berkaitan dengan perubahan ketentuan-ketentuan pidana karena keadaan darurat tindak pidana seksual terhadap anak yang terjadi dari tahun ke tahun yang semakin meningkat dam perbuatan pelaku terhadap anak makin sadis. Dengan adanya keadaan tersebut pembuat Undang-Undang kemudian melakukan perubahan dari sisi ketentuan pidana yaitu pidana penjara dan denda yang semakin tinggi, kemudian juga adanya pidana tambahan berupa pengumuman identitas hingga tindakan berupa pemasangan chip dan kebiri kimia mencegah terjadinya tindak pidanan kekerasan seksual terhadap anak. Namun ternyata kebijakan pemerintah yang diambil tersebut belum mampu menurunkan tingkat kejahatan terhadap anak, terutama kekerasan seksual terhadap anak.

Oleh karena garis kebijakan pertama dan kedua sebagaimana pembagian dari A. Mulder belum berhasil, maka perlu diupayakan cara lain yang tidak langsung ditujukan kepada pelaku namun ditujukan kepada anak korban. Hal tersebut dapat digunakan garis kebijakan ketiga yaitu perumusan kebijakan berkaitan dengan cara bagaimana penyidikan, penuntutan, peradilan dan pelaksanaan pidana harus dilaksanakan, sehingga perlindungan terhadap anak korban dapat dilaksanakan dengan lebih maksimal lagi.

Ketentuan pasal 58 ayat (3) huruf a dan b Undang-Undang Nomor 11 Tahun 2012 tentang Sistem Peradilan Pidana Anak sebenarnya menunjukkan bahwa hukum acara dalam Sistem Peradilan Pidana Anak mengakui alat bukti elektronik sebagai alat bukti yang sah yaitu keterangan anak korban dan/atau anak saksi dapat diberikan dengan perekaman elektronik dan pemeriksaan jarak jauh dengan audiovisual. Ketentuan ini memberikan kemungkinan bagi Anak Korban untuk memberikan keterangan diluar persidangan, dengan dihadiri oleh pembimbing kemasyarakatan, Penyidik atau Penuntut Umum dan Advokat atau pemberi bantuan hukum lainnya untuk yang melalui pemeriksaan jarak jauh dengan didampingi oleh orangtua/wali. Pembimbing Kemasyarakatan atau pendamping lainnya. 
Dengan diakuinya alat bukti elektronik dalam sistem peradilan anak, maka perlindungan terhadap anak korban kekerasan seksual dapat dilakukan lebih maksimal yaitu terhadap anak korban yang menjalani proses pidana yang nantinya akan menjadi saksi dalam perkara yang dilaporkannya, agar tidak terjadi reviktimisasi terhadap anak korban sehingga tidak timbul trauma lagi maka dalam memberikan keterangan tentang peristiwa kekerasan seksual yang dialaminya cukup dilakukan sekali saja yaitu saat pemeriksaan penyidikan, dengan ketentuan pada saat pemberian keterangan dihadiri oleh pendamping/pekerja sosial profesional/psikolog untuk memantau kondisi psikis anak korban, penyidik yang membuat Berita Acara Pemeriksaan, Advokat/pemberi bantuan hukum lainnya, petugas pemasyarakatan (bila pelaku anak) dengan melakukan perekaman elektronik dan pembuatan Berita Acara Pemeriksaan.

Berkaitan dengan sahnya keterangan saksi adalah dilakukan penyumpahan, maka hal tersebut telah diakomodir ketentuan Pasal 116 ayat (1) KUHAP yang menyatakan "saksi diperiksa dengan tidak disumpah kecuali apabila ada cukup alasan untuk diduga bahwa ia tidak akan dapat hadir dalam pemeriksaan di pengadilan."

Selanjutnya Pasal 162 ayat (1) dan ayat (2) KUHAP menyatakan:

Ayat (1) "Jika saksi sesudah memberikan keterangan dalam penyidikan meninggal dunia atau karena halangan yang sah tidak dapat hadir di sidang atau tidak dipanggil karena jauh tempat kediamannya atau karena tempat tinggalnya atau karena sebab lain yang berhubungan dengan kepentingan negara, maka keterangan yang telah diberikannya itu dibacakan."

Ayat (2) "Jika keterangan itu sebelumnya telah diberikan di bawah sumpah, maka keterangan itu disamakan nilainya dengan keterangan saksi dibawah sumpah yang diucapkan di sidang."

Pemerintah melalui pembentuk Undang-Undang dapat melakukan kebijakan perubahan hukum acara pidana yang terkait dengan cara pemeriksaan pada tahap penyidikan, penuntutan dan peradilan terhadap anak korban. Ketentuan seperti yang terdapat dalam Undang-Undang Nomor 11 Tahun 2012 tentang Sistem Peradila Pidana Anak, Pasal 58 ayat (3) “Dalam hal Anak Korban dan/atau Anak Saksi tidak dapat hadir untuk memberikan keterangan di depan sidang pengadilan, Hakim dapat memerintahkan Anak Korban dan/atau Anak Saksi di dengar keterangannya, huruf a "di luar sidang pengadilan melalui perekaman elektronik yang dilakukan oleh Pembimbing Kemasyarakatan di daerah hukum setempat dengan dihadiri oleh Penyidik atau Penuntut Umum dan Advokat atau pemberi bantuan hukum lainnya", dapat dijadikan sebagai dasar cara pemeriksaan terhadap anak korban sejak awal proses peradilan yaitu 
pada tahap penyidikan telah dilakukan perekaman eletronik, penyumpahan dan pembuatan Berita Acara Pemeriksaan, dan dapat dijadikan sebagai alat bukti sah pada proses penuntutan dan pembuktian.

Ketentuan-ketentuan dalam KUHAP menganut asas legalitas dan strictly atau restriktif sehingga tanpa adanya pengaturan yang tegas, hakim tidak boleh melakukan penafsiran sampai pada penemuan hukum baru dalam hukum acara. Penyimpangan dapat dilakukan dari KUHAP apabila secara khusus diatur dalam undang-undang. Aparat penegak hukum termasuk hakim selaku pelaksana perundang-undangan dalam sistem peradilan pidana akan melaksanakan suatu ketentuan apabila terdapat aturan yang tegas meskipun menyimpangi dari

peraturan umum karena ketentuan tersebut merupakan lex specialis dari ketentuan umum dan hal ini diperbolehkan dalam undang-undang.

\section{Penutup}

Dari hasil penelitian tersebut dapat disimpulkan bahwa reviktimasi terhadap anak korban kekerasan seksual masih terjadi karena proses peradilan pidana untuk anak korban sampai saat ini masih mengacu kepada UndangUndang Nomor 8 Tahun 1981 tentang Hukum Acara Pidana (KUHAP), ketentuan Pasal 58 ayat (1), (2) dan (3) Undang-Undang Nomor 11 Tahun 2012 tentang Sistem Peradila Pidana Anak hanya mengatur mengenai cara pemeriksaan anak korban pada saat memberikan keterangan di persidangan. Dengan mengacu pada KUHAP maka anak korban kekerasan seksual harus menjalani tahapan-tahapan proses peradilan, diantaranya adalah proses penyidikan dan proses persidangan. Pada setiap tahapan proses ini anak korban dapat mengalami penderitaan psikis karena harus kembali mengingat dan menceritakan kembali peristiwa yang dialaminya yang sebenarnya sudah tidak ingin diingatnya.Ketidaknyaman yang berulang seperti ini lama kelamaan dapat menyebabkan taruma. Keadaan seperti ini yang akan membuat anak korban mengalami viktimisasi kembali (revikimisasi). Pencegahan reviktimisasi terhadap anak korban kekerasan seksual dalam proses peradilan pidana merupakan salah satu bentuk perlindungan hukum terhadap anak secara psikis. Upaya perlindungan tersebut dapat dilakukan oleh Pemerintah dengan membuat kebijakan hukum melalui pembentuk Undang-Undang dengan melakukan perubahan hukum acara pidana yang terkait dengan cara pemeriksaan pada tahap penyidikan, penuntutan dan peradilan terhadap anak korban. Ketentuan seperti yang terdapat dalam Undang-Undang Nomor 11 Tahun 2012 tentang Sistem Peradilan Pidana Anak Pasal 58 ayat (3) huruf a, dapat dijadikan sebagai dasar cara pemeriksaan terhadap anak korban sejak awal proses peradilan yaitu pada tahap penyidikan telah dilakukan perekaman eletronik, penyumpahan 
dan pembuatan Berita Acara Pemeriksaan, dan dapat dijadikan sebagai alat bukti sah pada proses penuntutan dan pembuktian. Dengan demikian anak korban cukup sekali memberikan keterangan pada tahap penyidikan.

\section{Daftar Pustaka}

\section{Buku}

Abdussalam dan Adri Desasfuryanto, Victimology (Ilmu Tentang Korban), PTIK, Jakarta, 2018.

Ashofa, Burhan, Metode Penelitian Hukum, Rhineka Cipta, Jakarta, 2004.

Arief, Barda Nawawi, Masalah Penegakan Hukum dan Kebijakan Hukum Pidana dalam Penanggulangan Kejahatan, Kencana, Jakarta, 2014.

Gultom, Maidin, Perlindungan Hukum terhadap Anak dalam Sistem Peradilan Pidana Anak di Indonesia, cetakan keempat, Refika Aditama, Bandung, 2014.

Hadjon, Phillipus M. Hadjon, Perlindungan Hukum Bagi Rakyat Indonesia, Bina Ilmu, Surabaya, 1987.

Kansil, CTS Kansil, Pengantar Ilmu Hukum dan Tata Hukum Indonesia, Balai Pustaka, Jakarta, 1989.

Muhammad, Rusli, Sistem Peradilan Pidana Indonesia, UII Press, Yogyakarta, 2011.

Muladi dan Barda Nawawi Arif, Bunga Rampai Hukum Pidana, Alumni, Bandung, 2010.

Waluyo, Bambang, Viktimologi Perlindungan Korban dan Saksi, cetakan keenam, Sinar Grafika, Jakarta, 2018.

\section{Jurnal}

Rahmi, Atikah, “Urgensi Perlindungan bagi korban kekerasan seksual dalam sistem peradilan pidana terpadu berkeadilan gender", Mercatoria, vol. 11 (1), 2018.

\section{Internet}

Eddyono, Supriyadi W., "Pengantar Konvensi Hak Anak", http://lama.elsam.or.id/downloads/1262854039_20._Konvensi_Hak_An ak.pdf, diakses pada Juli 2019.

Quamila, Ajeng, "8 Trauma Fisik dan Mental Akibat Kekerasan Seksual", https://hellosehat.com/hidup-sehat/psikologi/trauma-akibatkekerasan-seksual/, diakses pada Maret 2020.

"Pengertian dan ruang lingkup kebijakan hukum pidana", http://www.definisipengertian.com/2015/05/pengertian-ruang-lingkup-kebijakanhukum.html, diakses tanggal 2 Agustus 2020.

\section{Undang-Undang}

Undang-Undang Nomor 17 Tahun 2016 tentang Penetapan Peraturan Pemerintah Pengganti Undang-Undang Nomor 1 Tahun 2016 tentang Perubahan 
306 IEx Renaissance NO. 2 VOL. 5 APRIL 2020: 287-306

Kedua atas Undang-undang Nomor 23 Tahun 2002 tentang Perlindungan Anak menjadi Undang-Undang.

Undang-Undang Republik Indonesia Nomor 11 Tahun 2012 tentang Sistem Peradilan Pidana Anak.

Undang-Undang Nomor 23 Tahun 2002 tentang Perlindungan Anak. 